$\xi=-1$

\title{
Effect of Bio-CNG Flow Rate on Modified Diesel Engine Run with Dual Fuel
}

\author{
Manjunath Channappagoudra ${ }^{* 1,}$ K. Ramesh ${ }^{2}$, Manavendra.G ${ }^{3}$ \\ ${ }^{* 1,2}$ Department of Mechanical Engineering, U.B.D.T College of Engineering, Davangere, Karnataka, India. \\ ${ }^{3}$ Department of Mechanical Engineering, B.I.E.T, Davangere, Karnataka, India. \\ *Corresponding author Email: manjunath6729@gmail.com
}

\begin{abstract}
In the first phase of investigation standard engine (SE) parameters are modified and optimized as Injector opening pressure (IOP) of 230 bar, Injection timing (IT) of 26.deg.bTDC, Compression ratio (CR) of 18, Nozzle hole (NH) of 5 hole and Piston bowl geometry (PBG) of Re-entrant toroidal piston bowl geometry (RTPBG)) when engine is operated with B20 (20\% dairy scum biodiesel+80\% diesel) fuel blend sole. The modified engine with these optimized parameters has shown improved brake thermal efficiency (BTE) when compared to standard engine operated with B20 (B20-SE), which could be attributed to improved fuel atomization, reduction of fuel droplet size, increased cylinder temperature, enhanced swirl and squish in the modified engine. In second phase of investigation, dual fuel (B20+BioCNG) experiments are conducted on modified engine to examine the effect Bio-CNG (enriched biogas/methane) flow rates such as 0.12, $0.24,0.36,0.48,0.60$ and $0.72 \mathrm{~kg} / \mathrm{hr}$ on modified engine performance, exhaust emission and combustion characteristics. Then dual fuel experimental results are compared with neat diesel and B20 fuel operations. The dual fueled engine with all Bio-CNG flow rates has resulted lower performance and combustion characteristics with increased emissions (HC and CO) when compared to single fuel (B20) operated engine. From dual operation, it concludes that $0.48 \mathrm{~kg} / \mathrm{hr}$ Bio-CNG flow rate has experienced the smooth running and improved performance, emission and combustion characteristics among all other Bio-CNG flow rates, hence $0.48 \mathrm{~kg} / \mathrm{hr}$ Bio-CNG flow rate is optimized.
\end{abstract}

Keywords: Diesel engine, Engine parameters, Nozzle hole geometry, Piston bowl geometry, Bio-CNG, Performance

\section{Introduction}

\section{1 Single Fuel Operation in Diesel Engine}

As industrialization and motorization growing day by day hence looking into substitute fuels for petroleum products which are locally available and lesser emissions than diesel is highly pronounced to curb the foreign exchange [1]. In this view, the transesterified biodiesels from non edible oils will substitutes the conventional diesel fuel [2]. The biodiesels are renewable, sustainable and exhibits similar properties as of petroleum diesel [3]. In other hand biodiesels have higher NOx emissions with higher biodiesel share as they are rich in oxygen in comparison with petroleum diesel [4].The utilization of biodiesels will not affect the weight loss and surface of the fuel injector equipment (FIE) hence lesser wear when compared with mineral diesel [5]. Minor modifications in diesel engine parameters like injector opening pressure (IOP), injection timing (IT), nozzle geometry and compression ratio (CR) will contributes the improved performance in the diesel engine fueled with biodiesels. The higher viscous and dense biodiesel needs higher IOP to ensure the proper fuel atomization followed by improved fuel-air mixing with smaller fuel droplets, complete combustion, improved combustion and emission behaviors of biodiesel run diesel engine [6-10]. In addition advanced fuel IT with biodiesel operation will enhance the engine performance and lowers the $\mathrm{HC}, \mathrm{CO}$ emissions with compromised higher NOx emission in comparison with petroleum diesel [11-13]. The diesel engine operate with biodiesel fuels will improves the performance, emission and combustion behaviors with higher compression ration than lower compression ratio (CR) as higher $\mathrm{CR}$ contributes more cylinder temperature and pressure led by complete combustion [14-17]. The design of nozzles hole is really a critical parameter to get improvement in spray characteristics succeeding emission and performance in combustion chamber when both experiment and simulation results are analyzed [18]. 20\% biodiesel with diesel would decreases the $\mathrm{HC}, \mathrm{CO}$ emissions except NOx emission even it is detrimental gas. Nozzle geometry modification (modifying injector nozzle hole from 5 (base) to 6 hole) could give a feasible solution to reduce NOx emission of biodiesel operated diesel engines [19]. Cavitation and turbulence presence in nozzle has a noteworthy influence on the succeeding spray behaviors [20]. At 250 bar injection pressure, brake thermal efficiency, brake specific fuel consumption are improved and emissions are decreased with modified nozzle ( 5 hole) when compared to baseline nozzle ( 3 hole) of the standard engine [21]. In 8 hole nozzle output power, brake specific fuel consumption and engine torque are increased a result of higher diesel injection velocity and improved fuel-air mixing with reduced NOx and $\mathrm{CO}$ emissions when compared to 6 , 7 and 9 holes [22]. The fuel injector nozzle with smaller orifice diameter would exhibit considerable engine performance, combustion and emission behaviors [23].

Along with injection strategies or change of other parameters of piston bowl shape strongly influences the engine performance [24]. From the numerical (CFD) simulations it is observed that the symmetric toroidal vortices of re-entrant piston bowl shapes will 
enhance the squish-swirl, turbulence kinetic energy (TKE) during compression stroke when compared to open-piston bowl shape which have bigger bowl diameter so therefore emissions will be decreased. Hence swirl, squish, turbulence are strongly influenced by the piston bowl geometry in diesel engines [25-27]. The combustion chamber with bottom corner will results the improved thermal efficiency and reduced NOx, CO and soot emissions when compared to lip shape and wall distance combustion chambers [28]. The diesel engine operation with $20 \%$ jatropha methyl ester has shown enhanced performance and reduced $\mathrm{HC}, \mathrm{CO}$ and smoke with re-entrant toroidal combustion chamber in comparison with spherical and toroidal combustion chambers [29]. The Toroidal Re-entrant Combustion Chamber (TRCC) geometries has shown the improved brake thermal efficiency, peak pressure and heat release rate (HRR) and reduced brake fuel consumption (BSFC), ignition delay period (IDP) $\mathrm{CO}, \mathrm{HC}$ and smoke as it contributes more air motion, squish and fuel-air mixing rate when compared to Hemispherical combustion chamber (HCC) [30].

\subsection{Dual Fuel Operation in Diesel Engine}

As the complete substitution of diesel for transport and agriculture sector is the major task now a days in India. In this regard biomass derive alternative fuels would give feasible solutions for these challenges. However, for dual fuel operation in diesel engine could reduce nitrogen oxide and smoke when compared to conventional diesel mode. Whereas dual fuel operation in diesel engine exhibits the inferior brake thermal efficiency and superior brake-specific energy consumption as well as exhaust gas temperature when compared to diesel fuel operation sole $[31,32]$. The biogas flow rates affect the brake thermal efficiency of the engine when it is operated in dual fuel. The brake thermal efficiency of the diesel engine would increase and specific energy consumption decreases with increase in methane concentration in the biogas. However specific fuel consumption of the CI engine is higher for dual operation when compared to neat diesel.

The $\mathrm{HC}$ and $\mathrm{CO}$ emissions of the engine are higher with increased biogas flow rate [33]. The engine would give 50\% lower thermal efficiency for dual fuel (Biogas and Diesel) operation when compared neat single fuel diesel as it contains more $\mathrm{CO}_{2}$ in it. However biogas is a promising substitute fuel and it can be produced easily at any place [34].

The application of dual fuel (biodiesel and biogas) in diesel engine exhibits lower NOx emissions and particulate matter with significantly reduced thermal efficiency when compared to diesel fuel operation. The optimum injection timing and optimum compression ratio would play prominent role on diesel engine performance operated with biogas-diesel dual fuel $[35,36]$. The higher compression of the diesel engine operated with rice bran oil biodiesel and biogas would give improved performance, combustion and emission characteristics [37]. The application of biogas in diesel engine is technically viable for power generation for rural areas [38]. Higher $\mathrm{CO}_{2}$ in biogas could reduce the brake thermal efficiency, smoke and NOx emissions, heat release rate and cumulative heat release are decreased whereas $\mathrm{HC}$ and $\mathrm{CO}$ emissions are increased however these $\mathrm{HC}$ and $\mathrm{CO}$ emissions can be controlled using different suitable methods. Hence raw biogas can be used in diesel engine with dual fuel operation [39]. Thermal barrier coating in diesel engine operated with biogas would give better performance in comparison with CNG fuel. The engine performance can also be increased with optimized injection parameters at different CNG flow rates [40]. The biogas production, up gradation and utilization of compressed biogas (CBG) or Bio-CNG would reduce the green house gases and global warming than fossil-based CNG and gasoline [41]. The biogas has lower calorific value than CNG however; NOx emission is lesser for biogas operation than CNG. Hence biogas is an eco-friendly and renewable fuel therefore enriched biogas would play a promising alternative fuel for the vehicles in coming days [42]. The liquefied bio-methane (LBM) or liquefied biogas
(LBG) which is obtained from upgradation and liquefaction of biogas would be the promising substitute fuel for the transportation. LBM has three times more energy dense than compressed bio-methane (CBM) [43]. The engine exhaust emissions namely $\mathrm{HC}, \mathrm{CO}$ and NOx are slightly higher with enriched biogas (Bio-CNG) than base compressed natural gas (CNG) with no significant change in fuel consumption for both enriched biogas and CNG. However the emission of enriched biogas in engines meets the BS IV emission norms. The properties of renewable enriched biogas are similar to fossil CNG hence exhibits better performance as of CNG. Hence enriched biogas could be used as auto fuel for spark ignition vehicles [44, 45].

Thus biodiesel-biogas duel fuel operation in internal combustion engines would be the future promising technology to preserve environment with no dependency on foreign fuels. In this regard rigorous research is highly pronounced to improve the diesel engine performance operated with dual fuel with suitable modifications in the engine. From the comprehensive literature it is observed that many researchers have studied the effect of piston bowl geometries with different simulation tools to appraise the engine performance. However there are limited works on dairy scum biodiesel-Bio-CNG dual fuel operated diesel engine. Hence in the present investigation objectives are framed with constructive hopes to realize the full potential use of dairy scum biodiesel and Bio-CNG in the direct injection diesel engine with modifying the piston bowl geometry and nozzles hole geometry along with some engine parameters namely IOP, IT, CR. The substandard performance of biodiesel-Bio-CNG operated diesel engine could be enhanced by providing better squish, turbulence, rapid and proper fuel-air mixing in the cylinder with robust design in piston bowl geometry, modifications in nozzle geometry and optimized engine parameters as the biofuels (biodiesel and Bio$\mathrm{CNG}$ ) have slight different properties as they are from different origins. In this regard, a sincere effort made on direct injection diesel engine to comprehend the complete utilization of biodieselBio-CNG in diesel engine with best piston bowl and nozzle hole geometry combined with best IOP, IT and CR.

\section{Materials and Methods}

\subsection{Biodiesel Preparation and Properties}

In the present investigation dairy scum biodiesel and Bio-CNG fuels are chosen to appraise the performance of the direct injection diesel engine. The properties of the fuels are evaluated as per ASTM- 6751. The properties of dairy scum biodiesel and Bio-CNG are given in Table 1 and Table2.

Table1: Properties of fuel blends.

\begin{tabular}{|l|l|l|l|l|}
\hline Properties & $\begin{array}{l}\text { Methods } \\
\text { IS } 1448\end{array}$ & Diesel & B20 & B100 \\
\hline Density $\left(\mathrm{kg} / \mathrm{m}^{3}\right)$ & P:16 & 830 & 840 & 870 \\
\hline Viscosity at $40^{0} \mathrm{C}(\mathrm{cSt})$ & $\mathrm{P}: 25$ & 2.9 & 2.98 & 4.36 \\
\hline Calorific value $(\mathrm{kJ} / \mathrm{kg})$ & $\mathrm{P}: 6$ & 43000 & 40890 & 38012 \\
\hline Flash Point $\left({ }^{\circ} \mathrm{C}\right)$ & $\mathrm{P}: 69$ & 50 & 58 & 130 \\
\hline Fire point $\left({ }^{\circ} \mathrm{C}\right)$ & $\mathrm{P}: 69$ & 60 & 68 & 142 \\
\hline
\end{tabular}

Table2: Properties of Bio-CNG

\begin{tabular}{|l|l|}
\hline Properties & \\
\hline Methane $\left(\mathrm{CH}_{4}\right)$ & $95-95.5 \%$ \\
\hline Carbon dioxide $\left(\mathrm{CO}_{2}\right)$ & $3-4.5 \%$ \\
\hline Hydrogen sulphide $\left(\mathrm{H}_{2} \mathrm{~S}\right)$ & Less than $5 \mathrm{ppm}$ \\
\hline Water vapour $\left(\mathrm{H}_{2} \mathrm{O}\right)$ & Nil \\
\hline Oxygen $\left(\mathrm{O}_{2}\right)$ & Nil \\
\hline Heating value $(\mathrm{HV})$ & $40 \mathrm{MJ} / \mathrm{kg}$ \\
\hline Density $\left(\mathrm{kg} / \mathrm{m}^{3}\right)$ & 0.75 \\
\hline
\end{tabular}




\subsection{Experimental Setup}

Kirloskar, $3.5 \mathrm{~kW}$ (TV1) diesel engine (Figure 1) is used to conduct the experiments. The standard engine specifications are given in Table 3. Instruments used for the defined work are diesel engine-test rig, ECU, Exhaust gas analyzer, burette and stopwatch, digital manometer, Chromel Alumel (K-Type) thermocouples. "Engine soft LV" software is employed for online combustion analysis. The combustion pressure at various crank angles is determined with using Piezo-sensor and crank angle sensor. The test engine is operated at $1500 \mathrm{rpm}$ constant speed and it is assembled with a dynamometer for loading the engine and it is provided water circulation to prevent overheating. Temperature sensors are provided for the measurement water jacket temperature, calorimeter water temperatures. The fuel and air flow rates are determined using flow sensors. Baseline engine readings are drawn fueled with pure diesel and average of three readings are considered for the examination.

In the present work B20 as liquid fuel (pilot fuel) and Bio-CNG as gaseous fuel (primary fuel) are used in the dual fuel engine. The Bio-CNG which filled in a cylinder of 160 bar is used as gaseous fuel in duel fuel operation. This high pressure Bio-CNG is converted to 2 bar using a two stage pressure regulator. Rotameter is employed to measure the Bio-CNG flow rate. The T-type gasair mixing chamber is used to mix the air and Bio-CNG properly before entering into the engine cylinder. Flash back flame arrestor is used in gas flow line to avoid the flash back and fire. In the present works, study aims to examine the effect of Bio-CNG in step of $0.12 \mathrm{~kg} / \mathrm{hr}(0.12,0.24,0.36,0.48,0.60$ and $0.72 \mathrm{~kg} / \mathrm{hr})$ on diesel engine performance. Data acquisition system is employed to determine the combustion characteristics of the diesel engine which operated with dual fuel. Airrex Automotive Emission Analyzer HG-540 is used to measure the exhaust emissions such as Hydrocarbons (HC), Carbon Monoxide (CO) and Oxides of Nitrogen (NOx)

Table3: TV1engine specifications.

\begin{tabular}{|l|l|}
\hline Parameters & Specifications \\
\hline Engine suppliers & Apex Innovations Pvt. Ltd \\
\hline Type & TV1 (Kirloskar) \\
\hline Cubic capacity & $661 \mathrm{cc}$ \\
\hline Bore and stroke length & $87.5 \mathrm{~mm} \mathrm{X} 110 \mathrm{~mm}$ \\
\hline Injector opening pressure & $210 \mathrm{bar}$ \\
\hline No. of Nozzle holes & 3 holes of $0.280 \mathrm{~mm}$ diameter \\
\hline Piston bowl geometry & Hemispherical \\
\hline Rated power & $3.5 \mathrm{~kW}$ \\
\hline Injection timing & $23^{0} \mathrm{bTDC}$ (diesel) \\
\hline Compression ratio & 17.5 \\
\hline
\end{tabular}

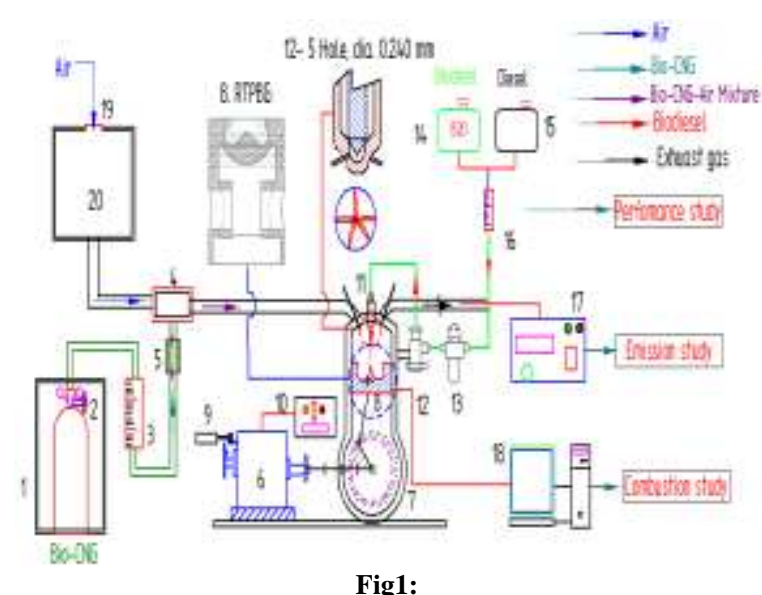

Fig1:

\subsection{Modifications in Engine}

The parameters of the standard diesel engines are appropriate for diesel fuel operation. However, rigorous research is required to optimize the engine parameters for biodiesel operation as they have different origin and properties. The tests are conducted on a Kirloskar standard engine (SE) (IOP: 210 bar, IT: 23.deg.bTDC, CR: 17.5 and NH: 3 ) with using $20 \%$ dairy scum biodiesel (B20). Later the standard engine IOP (210 bar) is varied from 210 bar to 240 bar in step of 10 bar $(210,220,230$ and 240 bar) and fuel injection timing using is changed in step of 3 degrees such as 20 , 23, 26 and 29.deg.bTDC. Similarly compression ratio (CR) is modified without altering the combustion chamber geometry to optimize the best compression among 16, 17 and 18. Later on the basis of the all above stated parameters brake thermal efficiency, the parameters are optimized as IOP: 230 bar, IT: 26.deg.bTDC, CR: 18 and these optimized parameters are carried further to examine the influence of the nozzle holes and piston bowl geometry. The specifications and photographic views of the nozzles are given in Table.4 and Figure $2 \& 3$. From the effect of nozzle hole study it is observed that nozzle with 5 holes exhibited better BTE when compared 3 and 4 holes hence it is optimized.

To ensure the better air-fuel mixing (swirl and squish) inside the cylinder is mainly depends on the piston bowl geometry in the direct injection diesel engine. In this study standard engine hemispherical piston bowl geometry (HPBG) which is centrally poisoned is modified into re-toriodal piston bowl geometry (RTPBG) without altering the bowl diameter (HPBG: $51 \mathrm{~mm}$ and RTPBG: $51 \mathrm{~mm}$ ) and bowl volume hence bowl volume is maintained same for both the pistons (HPBG bowl volume: $34727.95 \mathrm{~mm}^{3}$ and RTPBG: $34724.522 \mathrm{~mm}^{3}$ ). The concept behind this toroidal geometry is to utilize the complete oxygen by providing powerful squish. Schematic diagram with dimensions, photographic view and specifications of the piston bowl shapes are represented in Figure 4, Figure 5 and Table.5. From effect of piston bowl geometry study it is observed that piston bowl geometry of RTPBG has shown improved brake thermal efficiency among HPBG, SSPBG and TPBG hence it RTPBG is optimized as piston bowl geometry for B20 operation. Finally the existing baseline diesel engine is modified with the above all stated engine parameters. The modified engine (ME) (IOP: 230 bar, IT: 26.deg.bTDC, CR: 18, NH: 5, CC: RTPBG) with optimized parameters is carried further to investigate the effect of Bio-CNG flow rate on diesel engine performance, combustion and emission characteristics. The tests are conducted con diesel engine at various loads $(20 \%, 40 \%, 60 \%, 80 \%$ and $100 \%)$ to appraise the performance, combustion and emission behaviors of the diesel engine operated with $20 \%$ dairy scum biodiesel. At very beginning the standard engine is operated with diesel for some time to get base line readings. Then after experiments are carried with different parameters and combustion chambers, finally average of three readings are considered for performance assessment.

\begin{tabular}{|l|l|l|l|}
\hline Specifications & $\mathbf{3}$ hole & $\mathbf{4}$ hole & 5 hole \\
\hline $\begin{array}{l}\text { Number of } \\
\text { hole }\end{array}$ & 3 & 4 & 5 \\
\hline Part name & DLL110S639 & DLLA150S1211 & DLLA142S1033 \\
\hline $\begin{array}{l}\text { Hole } \\
\text { diameter(mm) }\end{array}$ & 0.280 & 0.210 & 0.240 \\
\hline Area $\left(\mathrm{mm}^{2}\right)$ & 0.0616 & 0.0346 & 0.0452 \\
\hline $\begin{array}{l}\text { Spray angle }(\theta \\
\left.0^{0}\right)\end{array}$ & 110 & 150 & 142 \\
\hline & & & \\
\hline
\end{tabular}

\begin{tabular}{|l|l|l|l|l|}
\hline Specifications & HPBG & SSPBG & TPBG & RTPBG \\
\hline $\begin{array}{l}\text { Bowl Volume (bv) } \\
\left(\mathrm{mm}^{3}\right)\end{array}$ & 34727.9 & 34727.0 & 34727.4 & 34724.5 \\
\hline $\begin{array}{l}\text { Throat radius (br) } \\
(\mathrm{mm})\end{array}$ & 51 & 51 & 51 & 41.93 \\
\hline $\begin{array}{l}\text { Bowl depth (bd) } \\
(\mathrm{mm})\end{array}$ & 25.5 & 19.19 & 17.15 & 20 \\
\hline $\begin{array}{l}\text { Piston diameter } \\
(\mathrm{mm})\end{array}$ & 87.5 & 87.5 & 87.5 & 87.5 \\
\hline
\end{tabular}




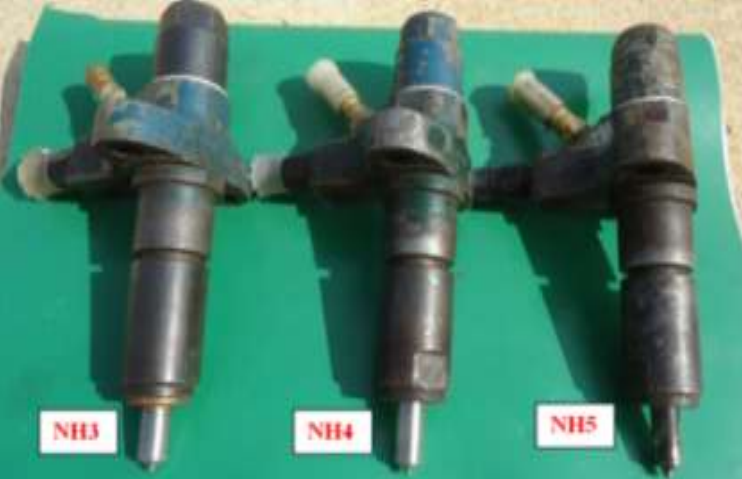

Fig.2: Photographic view of 3, 4 and 5 whole nozzle fuel injectors

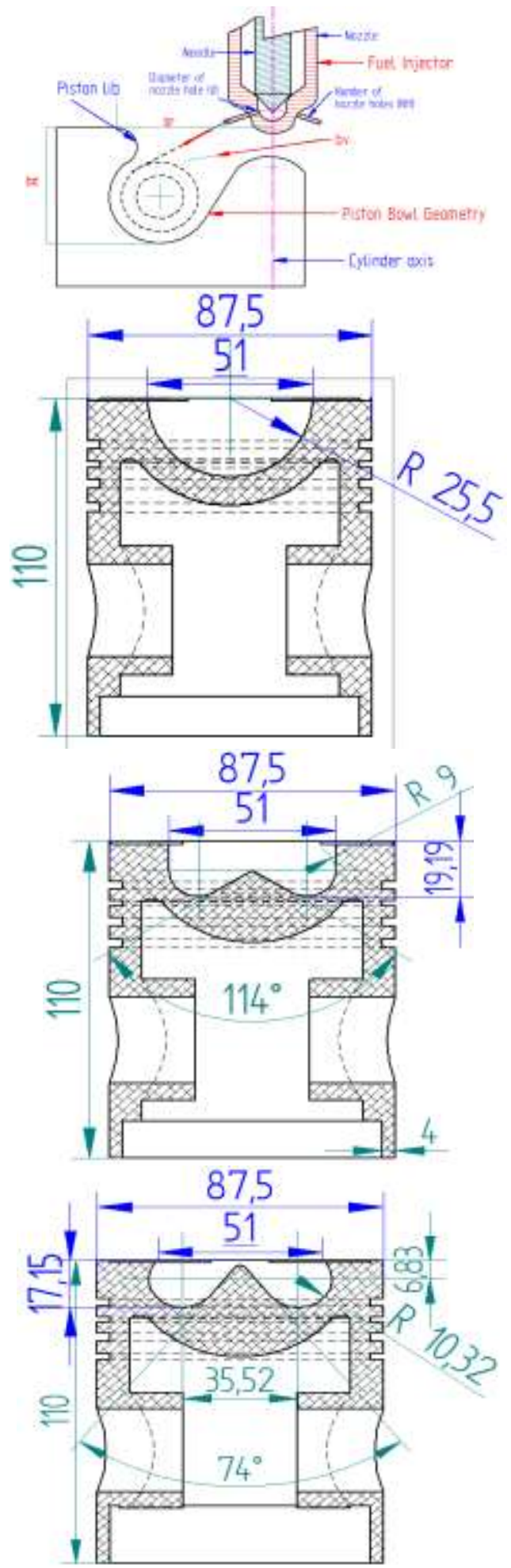

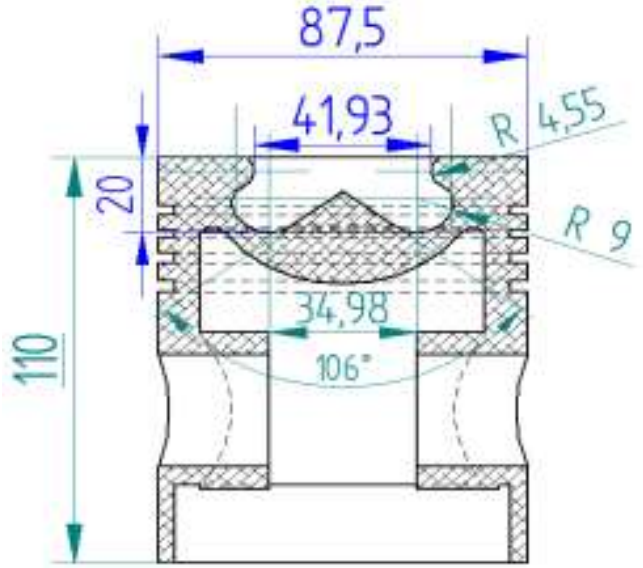

Fig.4. Schematic diagram photographic view of different piston bow shapes

Note: all dimensions are in $\mathrm{mm}$

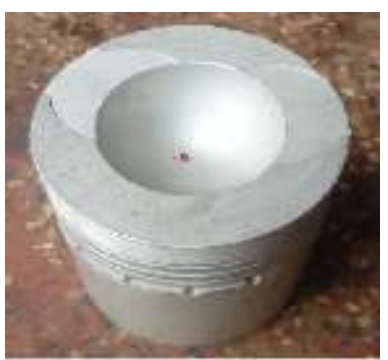

(a)HPBG

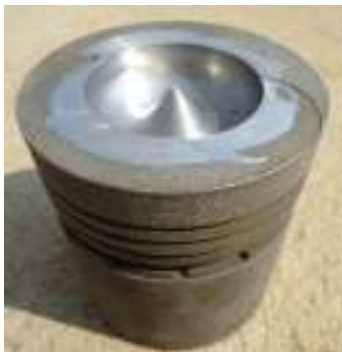

(b) TPBG

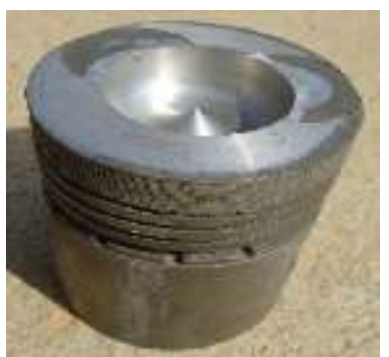

(b) SSPBG

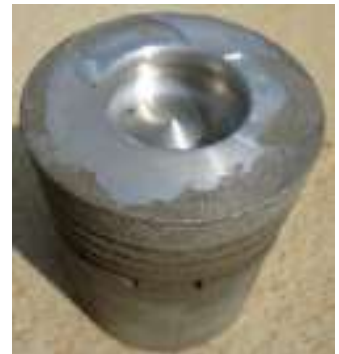

(c) TRPBG
Fig.5: Photographic view of different piston bowl geometry

\section{Results and Discussion}

\subsection{Brake Thermal Efficiency of Different Engine Parameters}

Figure 6 shows the deviation of BTE with BP for different IOPs. BTE is increased as the IOP increased the reason might be the improved atomization, vaporization; better air-fuel mixing leads better combustion. At 230 bar IOP enhanced air fuel mixing is observed during higher loads at compression process leads maximum BTE however it is lesser than diesel. This might be higher viscosity, low volatility, improper atomization and lower calorific value of B20 than diesel. The higher BTE of B20 $(30.55 \%)$ at 230 bar pressure is near to the petro-diesel $(31.32 \%)$ with 210 bar at full load condition. However B20 operation with 240 bar IOP, BTE is decreased (27.97\%) compared to 230 bar and 220 bar IOP (29.94\%) for all loads. The reason might be, too increased IOP will reduced the fuel droplet size, hence too finer (very small size) fuel droplets have lower momentum, delayed ignition, lower relative velocity and more fuel consumption at higher loads leads incomplete combustion by its own combustion products [9]. However, if the IOP is too high shorter ignition delay results hence probability of air-fuel mixing rate will be lower leads decreased burning rate and increased emissions in the engine. 210 bar IOP has shown lower BTE of $29.63 \%$ than 230 bar at full load. 
Among all IOPs 230 bar IOP has shown improved BTE hence it is optimized and carried further investigations.

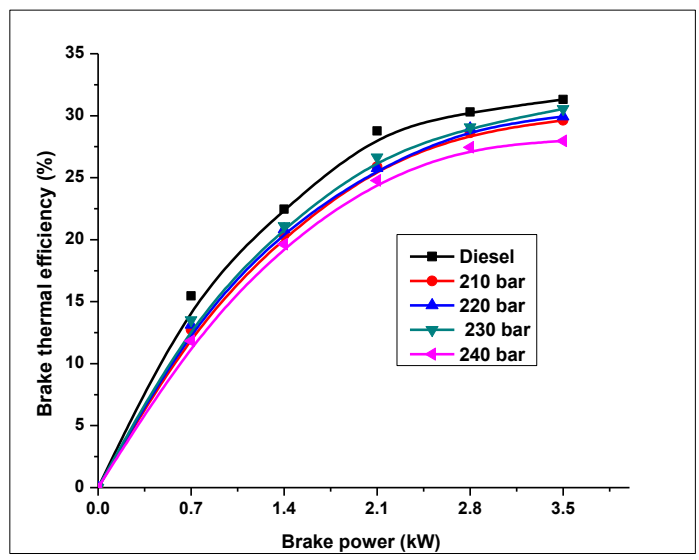

Figure 6: Brake thermal efficiency versus brake power.

Variation of BTE with BP for different injection timings are represented in figure 7 . The BTE increases with the increase in engine loads. Based on brake thermal efficiency fuel IT of 23.deg.bTDC (engine manufacturer) is the best for diesel. For B20, BTE decreased when compared with diesel fuel, at 23.deg.bTDC it might be attributed to inferior energy value, higher viscosity of the fuel and higher BSFC to produce the same power output as of diesel. As the IT is advanced from 23.deg.bTDC to 26.deg.bTDC BTE is increased which might be attributed to the more time availability for air-fuel mixing in the combustion chamber results improved combustion process therefore releases the more heat in. Whereas by retarding the IT from 23.deg.bTDC to 20.deg.bTDC might reduce the interaction time of air and fuel hence release the lower heat and slower burning process. From experimental study it is revealed that BTE values for Diesel-23.deg.bTDC, 20.deg.bTDC, 23.deg.bTDC, 26.deg.bTDC and 29.deg.bTDC are 31.32, 28.21, 30.5531 .03 and $29.15 \%$ respectively for the B20 operation at full load. For B20, 26.deg.bTDC is considered as the optimum injection timing as it has BTE of $31.03 \%$ near to Diesel BTE of $31.32 \%$. It is attributed to combination of low mass flow rate and volatility. Based on BTE values 26.deg.bTDC IT is the optimum for B20 operation.

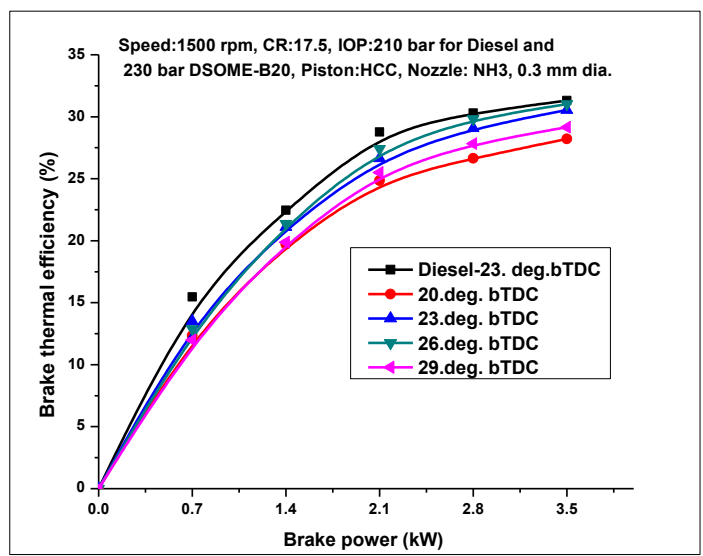

Figure 7: Brake thermal efficiency versus brake power.

Figure 8 depicts the variation of BTE with brake power for different compression ratios. The BTE for diesel is highest when compared to B20 with different compression ratios. It is because of higher calorific value and lower viscosity of the diesel fuel. As the compression ratio increased BTE is increased it may attributed to higher air temperature and better mixing of fuel and air in the cylinder results faster evaporation and complete combustion. At all full load when the compression ratio increased from CR 16 to CR 18 the BTE increased from $30.03 \%$ to $31.15 \%$ respectively. The BTE of increased CR 18 with DB20 operation is near to the diesel BTE of $31.32 \%$. From the results it's clear that CR 18 is the best compression ratio for $\mathrm{B} 20$ operation. The lower $\mathrm{CR}$ results lesser BTE it could be due to dilution of residual gas caused slower combustion.

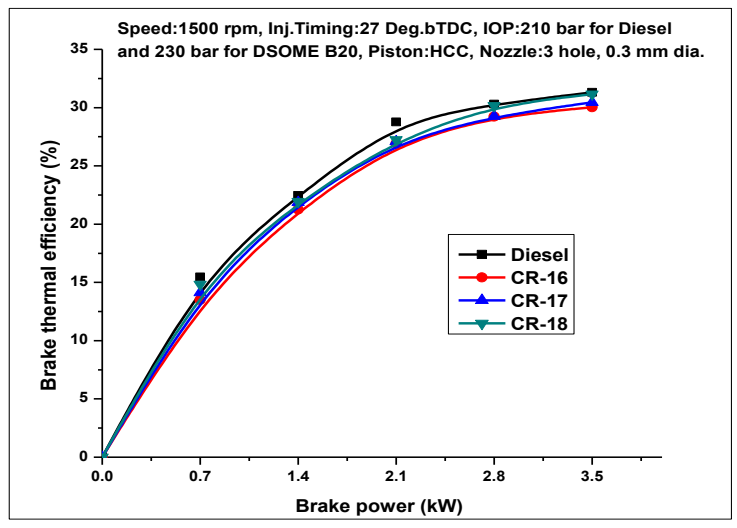

Figure 8: Brake thermal efficiency against brake power.

Figure 9 represents the deviation of BTE with brake power for different nozzles at different brake powers. The standard engine operation with diesel (Diesel-baseline) showed highest BTE of $31.32 \%$ when compared to other 3 and 4 hole nozzle operated with B20 fuel blend at maximum load. For optimized parameter engine (IOP:230 bar, IT:26.deg.bTDC, CR:18), 5 hole nozzle resulted higher BTE of $31.5 \%$ than 4 hole of $29.30 \%$ and 3 hole of $31.15 \%$, the reason for this might be better atomization and fuelair mixing inside the combustion chamber led rapid evaporation and combustion. In case of 4 hole BTE was decreased than 3 hole nozzle it could be attributed smaller fuel droplets sizes of 4 hole as it as smaller nozzle orifice diameter of $0.210 \mathrm{~mm}$ compare 3 $(0.280 \mathrm{~mm})$ and $5(0.240 \mathrm{~mm})$ hole. The smaller fuel droplet diameter will have lesser relative velocity and momentum hence partial suffocation with its own combustion products [6-7, 9]. The larger diameter (higher denser) fuel droplets have higher penetration and lesser velocity hence poor fuel-air mixing rate cause in complete combustion. For 5 hole nozzle injector with optimized engine parameters (IOP, IT and CR), $4.98 \%$ of increased BTE is observed when compared with baseline engine. Hence 5 hole nozzle injector with IOP: 230, IT: 26.deg.bTDC and CR: 18 are further carried to examine the effect of piston bowl geometry on diesel engine performance operated with B-20 fuel blend.

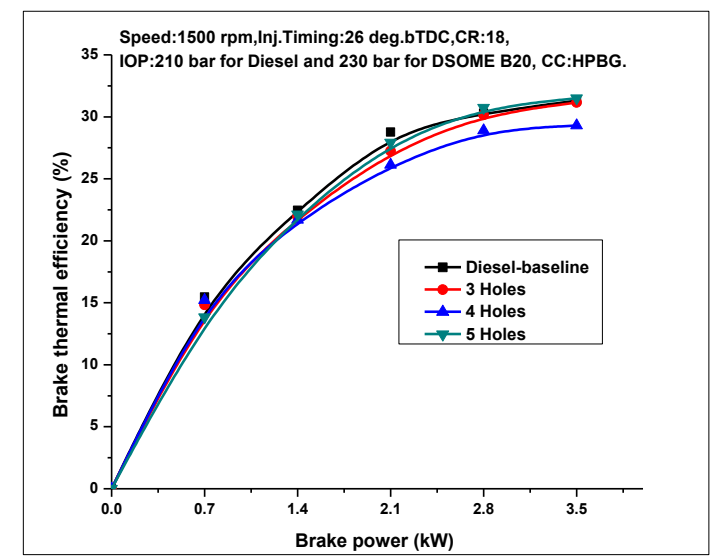

Fig.9: Brake thermal efficiency versus brake power. 
Figure 10 shows the distinction of BTE with brake power for standard, modified engine with different piston bowl geometries fueled with B20 fuel. In standard engine (SE) operation it is observed that BTE for B20 is lower $(29.93 \%)$ than petroleum diesel for all loads it could be due to lower calorific value, higher specific gravity and greater viscosity. Whereas modified engine (IOP:230 bar, IT:26.deg.bTDC, CR:18, NH:5 holes, CC:HPBG) has shown improved BTE (31.50\%) than SE (IOP:210 bar, IT:23.deg.bTDC, CR:17.5, NH:3 holes, CC:HPBG) engine operated with B20 which could be due to improved fuel atomization, increased cylinder temperature more time availability for fuel mixing rate will leads the faster oxidation and evaporation process hence cause better combustion. Where as in case of modified engine with TPBG has revealed the grater BTE of $31.69 \%$ than HPBG $(30.50 \%)$ and SSPBG (30.29\%) for maximum load range which is attributed enhance air motion in the TPBG leads better air-fuel mixture formation and evaporation led complete combustion. The BTE (32.28\%) value of RTPBG is greater than the all various piston bowls, which could be attributed to better swirl as entering of swirl air which spreads downwards and outward into the undercut region and then divides into streaming up the bowl sides and stream flowing along the bowl base. And also re-entrant cavity with round lip generates larger spray volumes and spray spreading. The fuel hits just on the lip corner produces the maximum spreading area and also corner radius helps to disperse the fuel accumulated at the bottom corner.

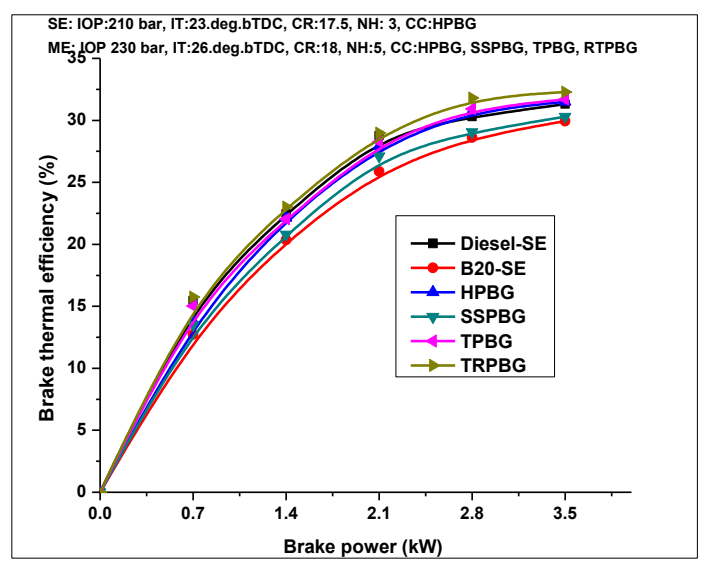

Fig.10: Brake thermal efficiency versus brake power.

\subsection{Effect of Bio-CNG Flow Rate on Diesel Engine Performance, Combustion and Emission Characteristics}

\subsubsection{Brake Thermal Efficiency}

Figure 11 shows the distinction of BTE with brake power for HPBG standard and modified engine fueled with B20 fuel. In standard engine (SE) operation it is observed that BTE for B20 is lower than petroleum diesel for all loads it could be due to lower calorific value, higher specific gravity and greater viscosity. Whereas modified engine (ME) has shown improved BTE than SE engine operated with B20 which could be due to improved fuel atomization, increased cylinder temperature more time availability for fuel mixing rate will leads the faster oxidation and evaporation process hence cause better combustion. The BTE results for Diesel-SE, B20-SE and B20-ME are found to be 31.32, 29.93 and $32.28 \%$ respectively at maximum load. Where as in case of modified engine with B20-ME has revealed the grater BTE than B20-SE for entire load range which is attributed enhanced air motion and heat transfer in the RTPBG leads proper mixing of burned and unburned fluid particles along with better air-fuel mixture formation and evaporation led complete combustion.

The dual fuel (B20+Bio-CNG) operation (DF) has resulted lower the brake thermal efficiency when compared to single fuel (B20)
[31, 32, 34-37]. This could be attributed lower pilot fuel injection and reduced oxygen content for the combustion when Bio-CNG is admitted into the cylinder. It also observed from graph that increase in Bio-CNG flow rate increases the ignition delay hence results the slower flame propagation in gas and air mixture when the Bio-CNG flow rate is greater than pilot fuel (B20). However with higher pilot introduction into the combustion chamber would helps to burn Bio-CNG properly and completely. The lower BioCNG flow rate has shown improved brake thermal efficiency as they exhibits better combustion. Whereas in case of higher BioCNG flow rate the thermal efficiency of the engine is lower, which attributed to higher gas flow rate would reduce the oxygen supply during the combustion. In Dual operation, the BTE increased to $3.84 \%$ when Bio-CNG flow rate is reduced to 0.12 $\mathrm{kg} / \mathrm{hr}$ from $0.72 \mathrm{~kg} / \mathrm{hr}$. The highest BTE obtained in dual fuel operation is with $0.12 \mathrm{~kg} / \mathrm{hr}$ flow rate of $23.9 \%$ among $0.24 \mathrm{~kg} / \mathrm{hr}$ (23.5\%), $0.36 \mathrm{~kg} / \mathrm{hr}(22.75 \%), 0.48 \mathrm{~kg} / \mathrm{hr}(22.155 \%)$, and 0.60 $\mathrm{kg} / \mathrm{hr}$ (21.475). From the experimental results its came to know that BTE of $0.12 \mathrm{~kg} . \mathrm{hr}$ operation decreased to $23.69 \%$ lesser than the diesel-SE operation, $20.14 \%$ lesser than B20-SE operation and $25.96 \%$ lesser than B2-ME operation.

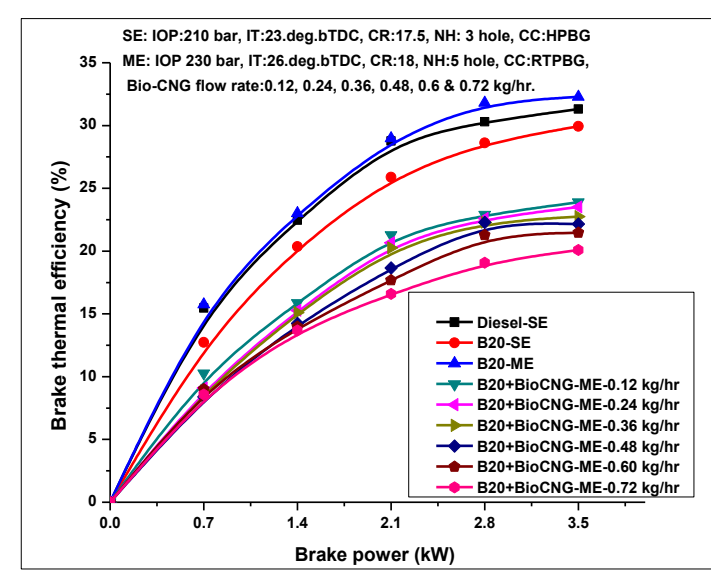

Figure 11: Brake thermal efficiency versus brake power.

However increase of Bio-CNG flow rate more than $0.48 \mathrm{~kg} / \mathrm{hr}$ engine started to knocking and observed engine vibration at higher loads hence $0.48 \mathrm{~kg} / \mathrm{hr}$ flow rate is optimized. Introduction of gaseous fuels results in very fast reaction rates hence cause very high pressure rise and uncontrolled combustion leads knocking. A small amount of increase in the gaseous fuel beyond a limit could result in very severe knocking $[46,47]$.

\subsubsection{Hydrocarbon Emission}

Figure 12 depicts the distinction of hydrocarbon (HC) emission levels with brake power for standard and modified engine. In standard engine operation the hydrocarbons emission at engine the exhaust is emitted is mainly due to wall quenching, lubricating oil burning and lean mixture. The concentration of $\mathrm{HC}$ in diesel engine varies as load and speed varies. The HC emissions are lower for DSOME operation compared to HS diesel for standard engine operation. This may due to increased gas temperature in the cylinder and more oxygen presence in the B20 in comparison with conventional diesel. The modified engine with B20-ME has resulted lower $\mathrm{HC}$ emission than standard engine B20-SE which is attributed to optimum engine parameter's effect in turn better fuel atomization, faster evaporation rate, and increased cylinder temperature. And also generation of more turbulent kinetic energy inside the re-entrant toroidal combustion chamber with improved air-fuel mixing leads better oxidation and combustion process with burning complete fuel which is admitted in the combustion chamber is also responsible for reduced $\mathrm{HC}$ emission in B20-ME when compared to B20-SE operation. The $\mathrm{HC}$ emissions values 
for Diesel-SE, B20-SE and B20-ME are found to be 45, 40, and $31 \mathrm{ppm}$ respectively at full load.

The HC emission for dual operation is more than the single fuel operation which could be attributed to insufficient oxygen availability in combustion process leads decreased volumetric efficiency and incomplete combustion with introduction of BioCNG into the cylinder when compared to single fuel operation. However the complete combustion can be achieved with supplying more amounts of air and injecting more amount of pilot fuel into the cylinder. In dual fuel operation, for all loads the HC emissions for all Bio-CNG flow rates are higher when compared to neat conventional diesel. This could be cause due to lower airBio-CNG mixture temperature leads slower combustion

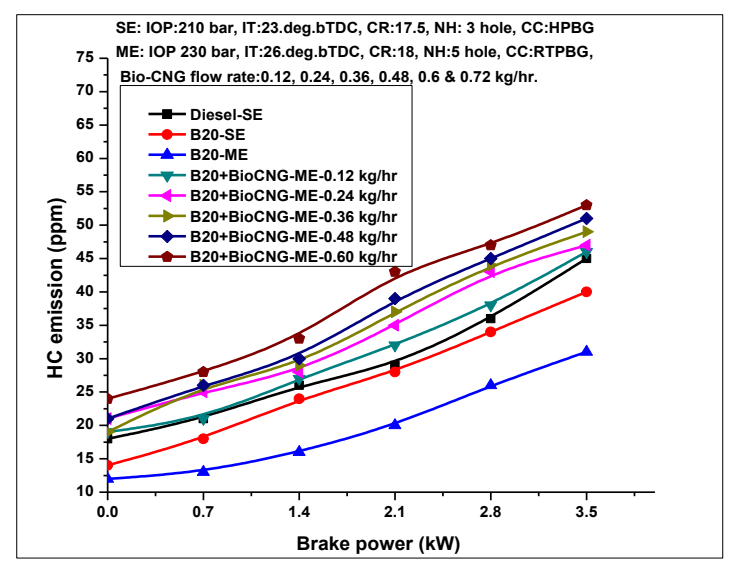

Figure 12: $\mathrm{HC}$ emission versus brake power.

From the graph it is noticed that as the Bio-CNG flow rate increased the $\mathrm{HC}$ emissions are increased with increased load, the reason might be lower oxygen availability and lesser charge temperature (air and Bio-CNG mixture) leads slower burning results higher $\mathrm{HC}$ emissions. $\mathrm{HC}$ emissions are slightly lower for lower Bio-CNG flow rates than higher Bio-CNG flow rates because lower Bio-CNG flow rates have more oxygen content in comparison with Higher Bio-CNG flow rates leads better combustion. In the dual fuel operation, $\mathrm{HC}$ emission level increased to $46 \mathrm{ppm}$ from $53 \mathrm{ppm}$ when the flow rate is increased from $0.12 \mathrm{~kg} / \mathrm{hr}$ to $0.72 \mathrm{~kg} / \mathrm{hr}$. The $\mathrm{HC}$ emission results for 0.12 , $0.24,0.36,0.48,0.60$ and $0.72 \mathrm{~kg} / \mathrm{hr}$ Bio-CNG flow rates at full load are found to be $46,47,49,51$, and $53 \mathrm{ppm}$ respectively. The lowest $\mathrm{HC}$ emission is resulted for $0.12 \mathrm{~kg}$.hr Bio-CNG flow rate among other flow rates.

\subsubsection{Carbon Monoxide Emission}

The comparison of carbon monoxide (CO) emission with brake power for standard and modified engine is represented in Figure 13. CO emission of biodiesel and their respective blends are lower than the conventional diesel due to cause of more oxygen content in the biodiesel leads complete oxidation and combustion. From graph it clears that the $\mathrm{CO}$ initially reduced with increasing because of at no load temperature of cylinder might be too low and later increased sharply up to maximum load. This may be due to the poor burning of the fuel with a very little time available for burning. The modified engine with B20 operation results lower $\mathrm{CO}$ emission than standard engine as the modified engine provides greater cylinder temperature to faster evaporation of the charge leads the faster oxidation to $\mathrm{CO}$ into $\mathrm{CO}_{2}$ hence reduces the $\mathrm{CO}$ emission. The standard engine operation with pure diesel (DieselSE) has resulted highest CO emission of $0.089 \%$ when compare to biodiesel operation (Both B20-SE and B20-ME operations), which could be attributed to lower oxygen presence in the diesel fuel when compare B20 hence lower oxidation and incomplete combustion leads higher $\mathrm{CO}$ emission.
The modified engine with toroidal piston bowl shape (B20-ME) has shown the lower CO emission of $0.062 \%$ when compared to standard engine hemispherical shape piston operation (B20-SE) of $0.076 \%$. Which attributed to improved air motion and squish in the cylinder releases the more heat with improved oxidation process hence increases the combustion temperature therefore it would enhance and combustion process. The unburned gas with less availability of the oxygen in the combustion chamber during combustion results lower oxidation and leads higher $\mathrm{CO}$ emissions. The $\mathrm{CO}$ emission levels for dual fuel operation at all loads is higher than single fuel operation with modified and without modified engine [40]. From the experimental results it observed that $0.12 \mathrm{~kg} / \mathrm{hr}$ Bio-CNG flow are has given lower CO emission of $0.0912 \%$ when compared to $0.72 \mathrm{~kg} / \mathrm{hr}$ Bio-CNG flow rate of $0.115 \%$. The $\mathrm{CO}$ emission experimental values for .24, $0.36,0.48$ and $0.60 \mathrm{~kg} / \mathrm{hr}$ are found to be $0.0945,0.0930,0.0994$ and $0.11 \%$ respectively at full load condition.

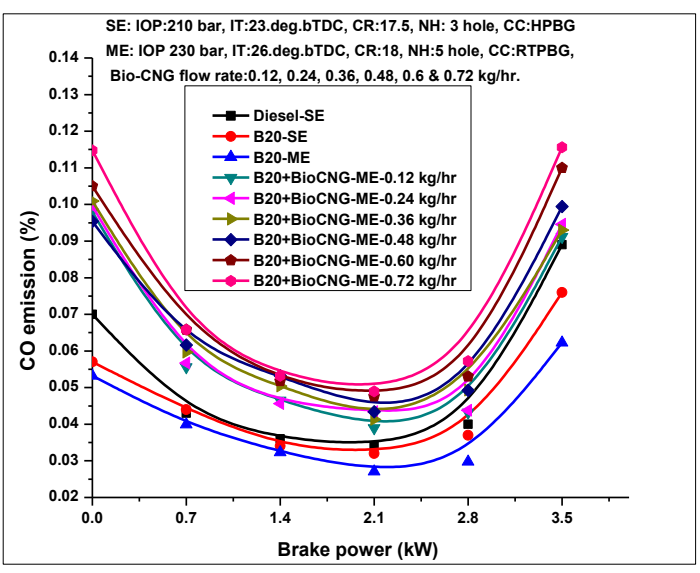

Figure 13: $\mathrm{CO}$ emission versus brake power.

\subsubsection{Oxides of Nitrogen Emission}

Figure 14 depicts the variations of NOx emissions for standard and modified engine with at different loads operated with B20. Cylinder temperature and oxygen presence in the fuel will results the NOx formation in diesel engine. As load increased nitrogen oxides also increased. NOx emission is found to be greater for B20 fuel when compared to petro-diesel for all loads. Higher HRR during premixed burning phase observed with biodiesel fuels led greater cylinder temperature and improved combustion. The NOx emission results for Diesel-SE, B20-SE and B20-ME are 961, 978 and $1164 \mathrm{ppm}$ respectively at maximum load. The modified engine with B20-ME has exhibited higher NOx emission in comparison with standard engine B20-SE which attributed improved turbulent motion of air with higher oxygen B20 intensifies the more heat release and heat transfer to the burned and unburned parts leads increased combustion temperature hence cause grater NOx formation in the B20-ME when compared to B20-ME. However these NOx emissions can be controlled with using exhaust gas recirculation (EGR). At higher loads, the NOx emission is lower for dual fuel operation when compared to single fuel operation. It is evident from the graph that NOx emission decreases with increased Bio-CNG flow rates with increased loads for dual fuel operation. Which is attributed lower gas and air mixture temperature and slower burning speed during combustion as increased amount of Bio-CNG flow rates reduces the oxygen concentration in the charge. Lowest NOx emission is noticed with $0.72 \mathrm{~kg} / \mathrm{hr}$ Bio-CNG flow rate when compared to other Bio-CNG flow rates. This could be due to lower combustion temperature of charge in the cylinder leads slower and improper combustion. At full load the experimental results for $0.12,0.24,0.36,0.48,0.6$ and $0.72 \mathrm{~kg} / \mathrm{hr}$ Bio-CNG flow rates are 875, 835, 781, 715, 674 and $641 \mathrm{ppm}$ respectively. 


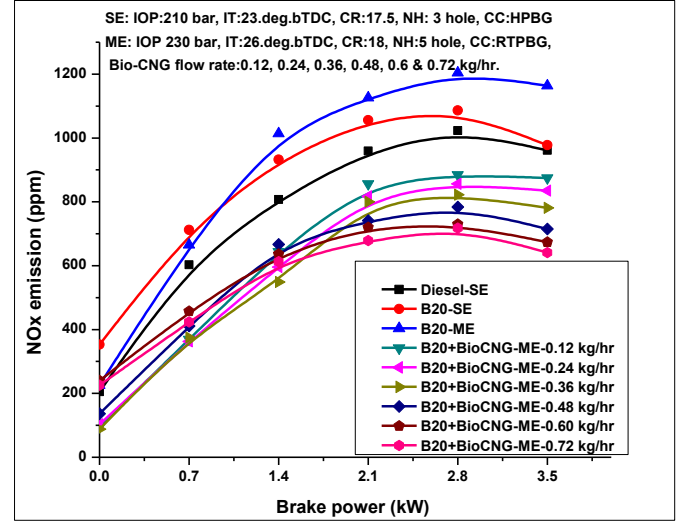

Figure 14: NOx emission versus brake power.

\subsubsection{Cylinder Pressure}

The deviations of cylinder pressure versus crank angle for standard engine and modified engine at full load are presented in Figure 15. Graph showed that peak cylinder pressure increased as load increased. In standard engine operation highest peak pressure is observed with diesel this may attributed to proper combustion as diesel has higher calorific value and lower viscosity and better burning of the fuel in rapid combustion phase with petro-diesel than B20. Whereas in case of B20-SE operation cylinder from the results it is observed that B20-ME resulted highest cylinder followed by B20-SE. The higher cylinder pressure with B20-ME is could be attributed to more turbulence intended higher flame speed will helps to rapid combustion fuel droplets which are entered into the combustion cavity leads the rapid combustion with increased pressure waves when the piston is at top dead centre (TDC) results highest cylinder pressure when compared to non-turbulent B20-SE. The cylinder pressure values for DieselSE, B20-SE and B20-ME are found to be 53.63, 52.29 and 55.42 bar respectively at higher load. The highest cylinder pressure with B20-ME is due to higher turbulence, increased chemical reactions, and increased flame front velocity results rapid rise of pressure in cylinder led increased cylinder pressure. The cylinder pressure affected by the amount of gaseous fuel introduced in the cylinder during ignition delay as well as rapid combustion period. The maximum cylinder pressure and cylinder temperature are observed for higher liquid fuel injection (B20) and lower Bio-CNG flow rate. This is due to higher liquid fuel injection than Bio-CNG would exhibits the improved flame front and combustion of airgas mixture results higher cylinder temperature and pressure.

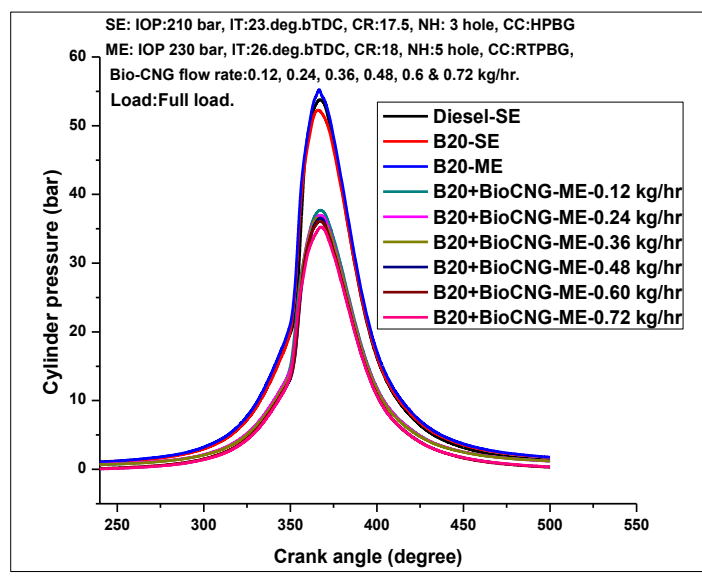

Figure 15: Cylinder pressure versus crank angle at full load.

However lower cylinder pressure and temperature with lower liquid fuel injection and higher Bio-CNG induction are observed, which could be attributed to slow burning of induced gaseous fuel in the combustion chamber during rapid combustion phase. The experimental results of peak pressure for $0.12,0.24,0.36,0.48$, 0.60 and $0.72 \mathrm{~kg} / \mathrm{hr}$ are $37.70,36.95,36.60,36.59,36.05$ and 35.30 bars respectively at maximum load

\subsubsection{Heat Release Rate}

Figure 16 depicts the rate of heat release profile versus crank angle for standard and modified engine at full load. Higher heating value and lower viscosity of the diesel results higher heat release rate (HRR) than B20-SE when engine operated at standard parameters. There is maximum HRR is observed with B20-ME (modified engine) operation when compared standard engine operation with B20-SE. This might be attributed to the improved air-fuel mixing rate, faster evaporation and combustion with optimized parameters of the engine fueled with B20. The HRR results for Diesel-SE, B20-SE and B20-ME are 65.43, 57.14, and $70.18 \mathrm{~J} / \mathrm{crank}$ angle respectively at maximum load. Engine operation with B20-ME has exposed the highest HRR in comparison with B20-SE, the reason for this could be enhanced chemical reaction with intimate mixing of fuel and air during the compression, hence higher turbulence results the complete burning of weak charge hence increase the heat releases and heat transfer to the cylinder wall.

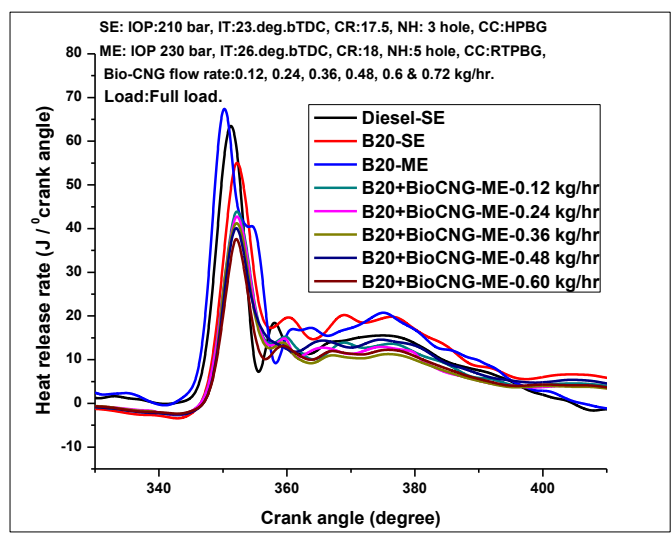

Figure 16: Heat release rate versus crank angle at full load.

Whereas in case of open type combustion chamber of B20-SE (HPBG) HRR is least amount as they more surface-volume ratio leads lower pressures and HRRs at different locations of the piston cavity cause lesser flame speed. Increase in the liquid fuel would increases the heat release rate and lowers the ignition delay. The reason might be increased liquid fuel would utilize the complete oxygen which is introduced in the cylinder during combustion leads improved combustion results increased HRR, reduced combustion duration and rapid heat transfer to the cylinder wall. Whereas in case of increased Bio-CNG flow rate ignition delay increases and HRR decreases which due to higher self ignition temperature of Bio-CNG, more heat loss during pre combustion with increased ignition delay and less availability of oxygen (at higher Bio-CNG flow rate air is replaced with Bio-CNG) at higher Bio-CNG flow rates leads incomplete combustion and lower HRR. The heat release rates for $0.12,024, .036,0.48,0.60$ and $0.72 \mathrm{~kg} / \mathrm{hr}$ are found to be $45.75,44.56,42.70,41.90$ and 40.10 $\mathrm{J} /{ }^{0} \mathrm{CA}$

\section{Conclusion}

In the present investigation, tests are conducted on diesel engine and optimized the engine parameter such as IOP, IT and CR on the basis of BTE. On the basis of BTE it is noticed that IOP of 230 bar, IT of 26.deg.bTDC, CR of 18, 5 hole nozzle and RTPBG 
piston has shown the improved BTE, hence these are optimized and modified (Modified Engine-IOP: 230 bar, IT; 26.deg.bTDC, CR: 18, NH: 5 holes, CC: RTPBG) the existing diesel engine (Standard Engine- IOP: 210 bar, IT: 23.deg.bTDC, CR: 17.5 and NH: 3 holes, CC: HPBG). Later study explores the effect of BioCNG flow rate on modified diesel engine performance, combustion and emission characteristics. Finally experimental results are compared with the standard diesel engine operated with diesel and B20 fuel blends.

The BTE is increased from $20.051 \%$ to $23.9 \%$ means $16.10 \%$ when Bio-CNG flow rate is decreased from $0.72 \mathrm{~kg} / \mathrm{hr}$ to 0.12 $\mathrm{kg} / \mathrm{hr}$. however increase in Bio-CNG flow rate more than 0.48 $\mathrm{kg} / \mathrm{hr}$, engine knocking is observed. In addition $0.48 \mathrm{~kg} / \mathrm{hr}$ flow rate has resulted higher BTE of $22.15 \%$ than all flow are except $0.12 \mathrm{~kg} / \mathrm{hr}$ hence it is optimized.

$\mathrm{HC}$ emission of $62 \mathrm{ppm}$ to $46 \mathrm{ppm}$ means $24.20 \%$ and $\mathrm{CO}$ emission of $0.115 \%$ to $0.0912 \%$ means $21.10 \%$ are increased when $0.12 \mathrm{~kg} / \mathrm{hr}$ Bio-CNG flow rate is increased to $0.72 \mathrm{~kg} / \mathrm{hr}$ flow rate. Whereas NOx emission is reduced from $875 \mathrm{ppm}$ to $641 \mathrm{ppm}$ means $26.74 \%$ when Bio-CNG flow rate is increased from $0.12 \mathrm{~kg} / \mathrm{hr}$ to $0.72 \mathrm{~kg} / \mathrm{hr}$.

The combustion characteristics like ignition delay is reduced from 14.95 to 13.91 deg. crank angle and combustion duration reduced from 56 to $51 \mathrm{deg}$. crank angle when Bio-CNG flow rate is reduced from $0.72 \mathrm{~kg} / \mathrm{hr}$ to $0.12 \mathrm{~kg} / \mathrm{hr}$.

Cylinder pressure is increased from 35.30 to 37.70 bar and HRR increased from 40.10 to $43.75 \mathrm{~J} / \mathrm{deg}$.crank angle when Bio-CNG flow rate is reduced from $0.72 \mathrm{~kg} / \mathrm{hr}$ to $0.12 \mathrm{~kg} / \mathrm{hr}$.

On whole experimental study it clears that modified engine with RTPBG-ME has shown improved performance, combustion and emissions when compared with modified (HPBG-ME) and standard engine (B20-SE) which could be attributed to improved fuel atomization, smaller size droplets, increased cylinder temperature swirl and squish, turbulent kinetic energy, higher flame front velocity of the charge during combustion. The 0.48 $\mathrm{kg} / \mathrm{hr}$ Bio-CNG flow rate would be the best flow rate among others; hence it could be successfully used in the modified engine with improved performance, combustion and emissions characteristics.

\section{Acknowledgement}

The authors are grateful to I \& D (Information and Demonstration on Biofuels) Centre, Biofuel Park Madenur, Hasan which is sponsored by Karnataka State Biofuel Development Board (KSBD), Govt. of Karnataka (India) for providing dairy scum biodiesel for research work. Authors would like to acknowledge the Managing Director of Apex Innovations, Sangli (India) for providing computerized experimental test setup to conduct the experiments.

\section{References}

[1] A.S. Ramadhas, S. Jayaraj, C. Muraleedharan. Use ofvegetable oils as I.C. engine fuels-A review. Renewable Energy 29 (2004) 727 742 .

[2] Deepak Agarwala, Lokesh Kumarb, Avinash Kumar Agarwal Performance evaluation of a vegetable oil fuelled compression ignition engine. Renewable Energy 33 (2008) 1147-1156.

[3] Radia Selaimia, Abdelsalem Beghiel, Rabah Oumeddour. The synthesis of biodiesel from vegetable oil. Procedia - Social and Behavioral Sciences 195 (2015) 1633 - 1638

[4] Peng Geng, Hongjun Mao, Yanjie Zhang, Lijiang Wei, Kun You, Ji Ju, Tingkai Chen. Combustion characteristics and NOx emissions of a iste cooking oil biodiesel blend in a marine auxiliary diesel engine. Applied Thermal Engineering 115 (2017) 947-954.

[5] M. Sarveshwar Reddy, Nikhil Sharma, Avinash Kumar Agarwal Effect of straight vegetable oil blends and biodiesel blends on wear of mechanical fuel injection equipment of a constant speed diesel engine. Renewable Energy 99 (2016) 1008-1018.
[6] D.T. Hountalas and D. A. Kouremenos, K. B. Binder, V. Schwarz, G. C. Mavropoulos. Effect of Injection Pressure on the Performance and Exhaust Emissions of a Heavy Duty DI Diesel Engine. 2003 SAE World Congress Detroit, Michigan, March 3-6, 2003.

[7] Venkanna Krishnamurthy Belagur and Venkataramana C. Reddy. Effect Of Injector Opening Pressures On The Performance, Emission And Combustion Characteristics of Di Diesel Engine Running on Honne Oil And Diesel Fuel Blend. Thermal Science: Year 2010, Vol. 14, No. 4, pp. 1051-1061.

[8] M. Badami, P. Nuccio and G. Trucco. Influence of Injection Pressure on the Performance of a DI Diesel Engine with a Common Rail Fuel Injection System. International Congress and Exposition Detroit, Michigan, March 1-4, 1999, 1999-01-0193.

[9] B.K.Venkanna, C.Venkataramana Reddy. Influence of injector opening pressures on the performance, emission and combustion characteristics of DI diesel engine running on calophyllum inophyllum linn oil (honne oil). International Journal of Renewable Energy, Vol. 6, No. 1, January - June 2011.

[10] Pritinika Behera \& S. Murugan. Studies on a diesel engine fuelled with used transformer oil at different fuel injection nozzle opening pressures. International Journal of Ambient Energy, 2013, Vol. 34, No. 1, 53-59.

[11] Senthil Ramalingam, Silambarasan Rajendran, Ravichandiran Nattan. Influence of injection timing and compression ratio on performance, emission and combustion characteristics of Annona methyl ester operated diesel engine. Alexandria Engineering Journal (2015) 54, 295-302.

[12] M. Mani, G. Nagarajan. Influence of injection timing on performance, emission and combustion characteristics of a DI diesel engine running on iste plastic oil. Energy 34 (2009) 1617 1623.

[13] Joonsik Hwang, Donghui Qi, Yongjin Jung, Choongsik Bae. Effect of injection parameters on the combustion and emission characteristics in a common-rail direct injection diesel engine fueled with iste cooking oil biodiesel. renewable Energy 63 (2014) 9-17.

[14] D. F. Melvin Jose, B. Durga Prasad, R. Edwin Raj \& Z. Robert Kennedy. An Extraction and Performance Analysis of Rubber Seed-Methyl Ester on an IC Engine at Various Compression Ratios. International Journal of Green Energy, 11: 808-821, 2014.

[15] T. Mohanraj \& K. Murugu Mohan Kumar. Operating Characteristics of a Variable Compression Ratio Engine Using Esterified Tamanu Oil. International Journal of Green Energy, 10: 285-301, 2013.

[16] G. Antony Miraculas1 N. Bose2 R. Edwin Raj. Optimization of Biofuel Blends and Compression Ratio of a Diesel Engine Fueled with Calophyllum inophyllumOil Methyl Ester. Arab J Sci Eng (2016) 41:1723-1733.

[17] Ashok Kumar Yadav, Mohd Emran Khan, Amit Pal. Kaner biodiesel production through hybrid reactor and its performance testing on a CI engine at different compression ratios. Egyptian Journal of Petroleum (2017) 26, 525-532.

[18] Avinash Kumar Agarwal, Sibendu Som, Pravesh Chandra Shukla, Harsh Goyal , Douglas Longman. In-nozzle flow and spray characteristics for mineral diesel, Karanja, and Jatropha biodiesels. Applied Energy 156 (2015)138-148.

[19] Subhash Lahane, K.A. Subramanian. Impact of nozzle holes configuration on fuel spray, wall impingement and NOx emission of a diesel engine for biodieselediesel blend (B20). Applied Thermal Engineering 64 (2014) 307-314.

[20] Zhixia He, Wenjun Zhong, Qian Wang, Zhaochen Jiang, Zhuang Shao. Effect of nozzle geometrical and dynamic factors on cavitating and turbulent flow in a diesel multi-hole injector nozzle. International Journal of Thermal Science 70 (2013):132-143.

[21] G. Vairamuthu1, S. Sundarapandian, B. Thangagiri. Use of calophyllum inophyllum biofuel blended with diesel in DI diesel engine modified with nozzle holes and its size. Heat Mass Transfer, 2015, DOI 10.1007/s00231-015-1623-2.

[22] B. Jafari, D.Domiri Ganji. Numerical Investigation in the Effect of Number of Nozzle Hole on Performance and Emission in Dual Fuel Engine. International Journal of Automotive Engineering Vol. 3, Number 2, June 2013.

[23] M. Vijay Kumar, A. Veeresh Babu and P. Ravi Kumar. Experimental investigation on the effects of diesel and mahua biodiesel blended fuel in direct injection diesel engine modified by nozzle orifice Diameters. Renewable Energy (2017), doi: 10.1016/j.renene.2017.12.007. 
[24] Arturo de Risi,Teresa Donate0 and Domenico Laforgia "Optimisation of the combustion chamber of direct injection diesel engines", Society of Automative Engineers, 2003-01-1064.

[25] F. Payri , J. Benajes, X. Margot, A. Gil, "CFD Modeling Of The InCylinder Flow In Direct-Injection Diesel Engines”, Computers \& Fluids 33 (2004) 995-1021.

[26] B.V.V.S.U. Prasad, C.S. Sharma, T.N.C. Anand, R.V. Ravikrishna, "High Swirl-Inducing Piston Bowls in Small Diesel Engines for Emission Reduction", Applied Energy 88 (2011) 2355-2367.

[27] Jino Song, Chunde Yao, Yike Liu and Zejun Jiang. Investigation on flow field in simplified piston bowls for DI diesel engine. Engineering Applications of Computational Fluid Mechanics Vol.2, No.3, pp.354-365 (2008).

[28] Pundlik R. GHODKE a and Jiwak G. SURYAWANSHI Investigation of diesel engine for low exhaustEmissions with different combustion chambers. THERMAL SCIENCE: Year 2015, Vol. 19, No. 6, pp. 2013-2024.

[29] Venkata Ramesh Mamilla , M.V.Mallikarjun , Dr. G.Lakshmi Narayana Rao "Effect of Combustion Chamber Design on a DI Diesel Engine Fuelled with Jatropha Methyl Esters Blends with Diesel", Procedia Engineering 64 ( 2013 ) 479 - 490.

[30] S. Jaichandar , K. Annamalai , "Effects of Open Combustion Chamber Geometries on The Performance of Pongamia Biodiesel In A DI Diesel Engine", Fuel 98 (2012) 272-279.

[31] Chandrakanta Nayak, Saroj Kumar Achrya and Ranjan Kumar Swain. "Performance of a twin cylinder diesel engine in dual fuel mode using woody biomass producer gas". International Journal of Sustainable Engineering, 2015, Vol. 8, No. 6, 341-348, http://dx.doi.org/10.1080/19397038.2014.977372.

[32] Chandrakanta Nayak, Saroj Kumar Achrya and Ranjan Kumar Swain. Performance of a twin cylinder dual-fuel diesel engine using blends of neat Karanja oil and producer gas. International Journal of Ambient Energy, 2016, Vol. 37, No. 1, 36-45, http://dx.doi.org/10.1080/01430750.2013.874370.

[33] Himsar Ambarita. Performance and emission characteristics of a small diesel engine run in dual-fuel (diesel-biogas) mode. Case Studies in Thermal Engineering 10 (2017) 179-191.

[34] Karen Cacua, Luis Olmos-Villalba, Bernardo Herrera, Anderson Gallego. Experimental evaluation of a diesel-biogas dual fuel engine operated on micro-trigeneration system for power, drying and cooling. Applied Thermal Engineering 100 (2016) 762-767.

[35] Bhaskor J. Bora, Ujjwal K. Saha. Optimization of injection timing and compression ratio of a raw biogas poared dual fuel diesel engine. Applied Thermal Engineering 92 (2016) 111-121.

[36] Bhaskor J. Bora, Ujjwal K. Saha. Comparative assessment of a biogas run dual fuel diesel engine with rice bran oil methyl ester, pongamia oil methyl ester and palm oil methyl ester as pilot fuels. Renewable Energy 81 (2015) 490-498.

[37] Bhaskor J. Bora, Ujjwal K. Saha. Experimental evaluation of a rice bran biodiesel e biogas run dual fuel diesel engine at varying compression ratios. Renewable Energy 87 (2016) 782-790.

[38] Debabrata Barik, Ashok Kumar Satapathy \& S. Murugan. Combustion analysis of the diesel-biogas dual fuel direct injection diesel engine - the gas diesel Engine. International Journal of Ambient $\quad$ Energy, 2015 , http://dx.doi.org/10.1080/01430750.2015.1086681.

[39] Sunmeet Singh Kalsi, K.A. Subramanian. Effect of simulated biogas on performance, combustion and emissions characteristics of a bio-diesel fueled diesel engine. Renewable Energy 106 (2017) 7890.

[40] B. Nageswara Rao, B. Sudheer Prem Kumar \& K. Vijaya Kumar Reddy. Effect of CNG flow rate on the performance and emissions of a Mullite-coated diesel engine under dual-fuel mode. International Journal of Ambient Energy, 2016, Vol. 37, No. 6 , 589-596, http://dx.doi.org/10.1080/01430750.2015.1023835.

[41] Seksan Papong , Paritta Rotwiroon , Thawach Chatchupong Pomthong Malakul. Life cycle energy and environmental assessment of bio-CNG utilization from cassava starch istewater treatment plants in Thailand. Renewable Energy 65 (2014) 64-69.

[42] Cheolsoo Lim, Daigon Kim, Changkeun Song, Jeongsoo Kim, Jinseok Han, Jun-Seok Cha. Performance and emission characteristics of a vehicle fueled with enriched biogas and natural gases. Applied Energy 139 (2015) 17-29.

[43] Laura Annamaria Pellegrini, Giorgia De Guido, Stefano Lang. Biogas to liquefied biomethane via cryogenic upgrading technologies. Renewable Energy xxx (2017) 1-9. http://dx.doi.org/10.1016/j.renene.2017.08.007.

[44] K.A. Subramanian, Vinaya C. Mathas, V.K. Vijay, P.M.V Subbarao. Comparative evaluation of emission and fuel economy of an automotive spark ignition vehicle fuelled with methane enriched biogas and CNG using chassis dynamometer. Applied Energy 105 (2013) 17-29.

[45] R. Chandra, V.K. Vijay, P.M.V. Subbarao, T.K. Khura. Performance evaluation of a constant speed IC engine on CNG, methane enriched biogas and biogas. Applied Energy 88 (2011) 3969-3977.

[46] G.H. Abd Alla, H.A. Soliman, O.A. Badr, M.F. Abd Rabbo. Effect of pilot fuel quantity on the performance of a dual fuel engine. Energy Conversion \& Management 41 (2000) 559-572.

[47] M.L. Mathur and R.P. Sharma. Internal Combustion Engine, Dhanpat Rai Publications (P) Ltd, ISBN: 978-81-89928-46-9, 1976. 